\title{
Процесуальний порядок здійснення заходів із виявлення та розшуку майна, на яке може бути накладено арешт
}

\author{
Плюшкін А. Ю. \\ аспірант кафедри кримінального прочесу \\ Національна академія внутрішніх справ \\ пл. Солом'янська, 1, Київ, Украӥна \\ orcid.org/0000-0002-7964-0654 \\ plartem1986@gmail.com
}

Ключові слова: майно, активи, способи збирання доказів, процесуальний порядок виявлення та розшуку майна, на яке може бути накладено арешт, арешт майна, прокурор, слідчий, Національне агентство України з питань виявлення, розшуку та управління активами, одержаними від корупційних та інших злочинів.
У статті досліджується процесуальний порядок здійснення заходів з виявлення та розшуку майна, на яке може бути накладено арешт. Автор провів ретельний та всебічний аналіз кримінального процесуального законодавства та наукової літератури щодо способів збирання доказів у контексті здійснення заходів 3 виявлення та розшуку майна з метою подальшого арешту.

Детально проаналізовано способи збирання доказів, передбачені Кримінальним процесуальним кодексом України, в контексті здійснення заходів з виявлення та розшуку майна. Досліджено співвідношення таких способів збирання доказів, як витребування та отримання речей і документів, тимчасовий доступ до речей і документів, а також проведення обшуку.

Приділено увагу порядку взаємодії Національного агентства України 3 питань виявлення, розшуку та управління активами, одержаними від корупційних та інших злочинів, зі слідчими, детективами, прокурорами, органами досудового розслідування, органами прокуратури 3 питань виявлення та розшуку активів (коштів, майна, майнових та інших прав), на які може бути накладено арешт у кримінальному провадженні. Акцентовано увагу на важливості використання слідчими та прокурорами всіх передбачених кримінальним процесуальним законом способів збирання доказів під час здійснення заходів з виявлення та розшуку майна. 


\section{Procedural order of implementation of measures finding and tracing property that may be arrested}

Pliushkin A. Yu.

Postgraduate Student at the Department Criminal Procedure

National Academy of Internal Affairs

Solomianska square, 1, Kyiv, Ukraine

orcid.org/0000-0002-7964-0654

plartem1986@gmail.com

Key words: property, assets, methods of collecting evidences, procedural order of finding and tracing property that may be arrested, arrest of property, prosecutor, investigator, National Agency of Ukraine for Finding, Tracing and Management of Assets Derived from Corruption and Other Crimes.

\begin{abstract}
The article examines the procedural order of the implementation by the investigator and prosecutor of measures finding and tracing property that may be arrested. The author conducted a thorough and comprehensive analysis of criminal procedure law and the scientific literature about the methods of collecting evidences in the context of the implementation of measures finding and tracing property that may be seized.

Methods of collecting evidences, provided the Criminal Procedure Code of Ukraine, in the context of the implementation of measures finding and tracing property are detaily analyzed. The correlation of such methods collecting evidences as requesting and receiving objects and documents, temporary access to objects and documents, as well as conducting a search has been studied.

Attention is paid to the procedure of interaction of the National Agency of Ukraine for finding, tracing and management of assets derived from corruption and other crimes with investigators, detectives, prosecutors, pretrial investigation bodies, prosecutor's offices for finding and tracing of assets (funds, property, property and others rights) that may be seized in criminal proceedings. Emphasis is placed on the importance of the use by investigators and prosecutors of all methods of collecting evidences provided by the criminal procedure law in the implementation of measures for finding and tracing for property that may be arrested.
\end{abstract}

Вступ. Законом України «Про Національне агентство України з питань виявлення, розшуку та управління активами, одержаними від корупційних та інших злочинів» від 10 листопада 2015 року частину першу статті 170 Кримінального процесуального кодексу України (далі - КПК України) доповнено реченням щодо необхідності вжиття слідчим, прокурором заходів з метою виявлення та розшуку майна, на яке може бути накладено арешт у кримінальному провадженні, зокрема шляхом витребування необхідної інформації в Національного агентства України з питань виявлення, розшуку та управління активами, одержаними від корупційних та інших злочинів, інших державних органів та органів місцевого самоврядування, фізичних і юридичних осіб [1].

Ці прийняті до кримінального процесуального законодавства зміни встановлюють необхідність визначення процесуального порядку здійснення заходів 3 виявлення та розшуку майна, на яке може бути накладено арешт.
Окремі питання способів збирання доказів, порядок проведення слідчих та негласних слідчих (розшукових) дій, заходів забезпечення, витребування та отримання речей і документів досліджувалися такими вченими, як: Ю.І. Азаров, В.В. Вапнарчук, В.В. Давидюк, О.В. Капліна, С.О. Ковальчук, О.В. Ковтун, В.М. Тертишник, B.I. Фаринник, I.M. Чемерис та ін.

Однак відсутність комплексних наукових праць стосовно процесуального порядку здійснення заходів 3 виявлення та арешту майна 3 метою накладення арешту підтверджує актуальність дослідження даної проблематики та необхідність аналізу законодавства та наукової думки в даному контексті.

Постановка завдання. Мета статті полягає в дослідженні кримінального процесуального законодавства щодо процесуального порядку здійснення заходів з виявлення та розшуку майна, зокрема способами збирання доказів, визначеними кримінальним процесуальним законом. 
Виклад основного матеріалу дослідження. Визначаючи процесуальний порядок здійснення заходів 3 виявлення та розшуку майна 3 метою накладення арешту, варто зауважити, що кримінальний процесуальний закон не визначає порядок ужиття слідчим та прокурором зазначених заходів, вказуючи лише на можливість витребування необхідної інформації в Національного агентства України 3 питань виявлення, розшуку та управління активами, одержаними від корупційних та інших злочинів, інших державних органів та органів місцевого самоврядування, фізичних і юридичних осіб [2].

Однак необхідно вказати, що здійснення заходів 3 виявлення та розшуку $є$ фактично одним 3 елементів процесуального доказування - збирання доказів, водночас спрямованого на отримання доказів існування майна, на яке може бути накладено арешт.

Збирання доказів у кримінальному процесі здебільшого визначають як елемент доказування, змістом якого є здійснення уповноваженим (компетентним) державним органом пошуково-пізнавальних дій 3 метою сприйняття інформації, що міститься в слідах кримінального правопорушення, iii вилучення та закріплення в матеріалах кримінального провадження [3, с. 290].

Водночас необхідно зазначити, що у ч. 2 ст. 171 КПК України вказується, що у клопотанні слідчого, прокурора про арешт майна повинно бути зазначено про документи, які підтверджують право власності на майно, що належить арештувати, або конкретні факти й докази, що свідчать про володіння, користування чи розпорядження підозрюваним, обвинуваченим, засудженим, третіми особами таким майном.

Тобто на слідчого та прокурора, окрім обов'язку вжиття заходів з виявлення та розшуку майна, покладено фактично обов'язок перевірки отриманих відомостей та інформації щодо їх належності, достовірності та допустимості, оскільки надалі такі відомості та інформація, відображені у відповідних документах, будуть надані суду в підтвердження поданого клопотання про арешт.

Із внесенням змін до КПК України щодо необхідності здійснення слідчим та прокурором заходів 3 виявлення та розшуку майна законодавець указав насамперед на можливість витребування необхідної інформації у Національного агентства України з питань виявлення, розшуку та управління активами (далі - Національне агентство).

Ст. 15 Закону України «Про Національне агентство України 3 питань виявлення, розшуку та управління активами, одержаними від корупційних та інших злочинів» встановлює, що Національне агентство взаємодіє 3 органами досудового розслідування, прокуратури та суду, зокрема шляхом виконання звернень слідчого, детектива, прокурора, слідчого судді, суду 3 питань виявлення, розшуку, проведення оцінки та управління активами, а також щодо виконання рішень іноземних компетентних органів про накладення арешту та конфіскацію активів.

Окрім того, згідно зі ст. 17 цього ж Закону Національне агентство забезпечує виконання звернень органів досудового розслідування, прокуратури та судів щодо виявлення, розшуку активів та надає відповідь у найкоротший можливий строк, але не пізніше, ніж протягом трьох робочих днів із дня надходження звернення або в інший, більш тривалий строк, зазначений у ньому. Цей строк може бути продовжений за погодженням 3 органом досудового розслідування, прокуратури та судом.

3 метою більш ефективної взаємодії під час здійснення заходів 3 виявлення та розшуку активів між органами досудового розслідування та прокуратури, з однієї сторони та Національним агентством - 3 іншої, спільним наказом Національного агентства України з питань виявлення, розшуку та управління активами, одержаними від корупційних та інших злочинів, Національного антикорупційного бюро України, Генеральної прокуратури України, Служби безпеки України, Міністерства внутрішніх справ України, Міністерства фінансів України від 20 жовтня 2017 року № 115/197-о/297/586/869/857 затверджено Порядок взаємодії при розгляді звернень органів, що здійснюють досудове розслідування, прокуратури та виконанні запитів іноземних держав щодо виявлення та розшуку активів (далі - Порядок) [4]. Зазначений Порядок визначає засади взаємодії між Національним агентством та слідчими, детективами, прокурорами, органами досудового розслідування, органами прокуратури 3 питань виконання Національним агентством звернень слідчих, детективів, прокурорів, органів досудового розслідування, органів прокуратури щодо виявлення та розшуку активів (коштів, майна, майнових та інших прав), на які може бути накладено арешт у кримінальному провадженні.

Зокрема, в Порядку встановлюються суб'єкти звернення, якими є слідчий, детектив, прокурор, які діють у межах повноважень, що підтверджуються витягом з Єдиного реєстру досудових розслідувань, а також органи, що здійснюють досудове розслідування, та органи прокуратури в особі їхніх керівників, вимоги до оформлення та змісту звернень, підстави для відмови розгляду, строки їх розгляду та безпосередньо вимоги до результатів розгляду цих звернень.

Важливими критеріями встановлених вимог до звернення $є$ факт внесення відомостей про вчинене кримінальне правопорушення до Єдиного 
реєстру досудових розслідувань, що підтверджується відповідним витягом, стислий опис фабули кримінального провадження та правова кваліфікація кримінального правопорушення із зазначенням статті (частини статті) Кримінального кодексу України. Наявність цих критеріїв фактично вказує на існування підстав для здійснення слідчим та прокурором заходів 3 виявлення та розшуку майна, на яке можливо накласти арешт у кримінальному провадженні.

У свою чергу за результатами вжитих заходів 3 виявлення, розшуку активів Національне агентство складає відповідь на звернення, в якому зазначаються встановлені відомості, що свідчать про існування активів, на які може бути накладено арешт у кримінальному провадженні, а також про їх місцезнаходження чи останнє відоме місцезнаходження.

При цьому в разі встановлення Національним агентством за результатами вжиття заходів 3 виявлення, розшуку активів ознак правопорушень, не вказаних у зверненні, відповідним правоохоронним органам надсилається висновок, який є обов'язковим для розгляду ними.

Водночас під час здійснення заходів 3 виявлення та розшуку майна, на яке можливо накласти арешт, кримінальний процесуальний закон зобов'язує слідчого та прокурора не обмежуватися лише зверненням до Національного агентства, а й витребовувати інформацію в інших державних органів та органів місцевого самоврядування, фізичних і юридичних осіб.

Можливість витребування та отримання слідчим та прокурором як стороною обвинувачення від органів державної влади, органів місцевого самоврядування, підприємств, установ та організацій, службових і фізичних осіб речей, документів, відомостей, які можуть містити інформацію про майно, є одним із засобів збирання доказів, передбачених ст. 93 КПК України.

Зокрема, згідно зі ст. 93 КПК України збирання доказів здійснюється шляхом проведення слідчих (розшукових) дій та негласних слідчих (розшукових) дій; витребування та отримання від органів державної влади, органів місцевого самоврядування, підприємств, установ та організацій, службових та фізичних осіб речей, документів, відомостей, висновків експертів, висновків ревізій та актів перевірок; проведення інших процесуальних дій, передбачених цим Кодексом, а також одержання доказів на території іноземної держави в результаті здійснення міжнародного співробітництва під час кримінального провадження.

У зв'язку з цим доцільно розглянути питання можливості здійснення заходів з виявлення та розшуку майна, на яке може бути накладено арешт, кожним із зазначених способів збирання доказів.
Збиранню доказів шляхом проведення слідчих (розшукових) дій та негласних слідчих (розшукових) дій приділено увагу у главах 20 та 21 КПК України. Частина 1 статті 223 КПК України вказує, що слідчі (розшукові) дії є діями, спрямованими на отримання (збирання) доказів або перевірку вже отриманих доказів у конкретному кримінальному провадженні. У свою чергу, у ч. 1 ст. 246 КПК України зазначається, що негласні слідчі (розшукові) дії є різновидом слідчих (розшукових) дій, відомості про факт та методи проведення яких не підлягають розголошенню, за винятком випадків, передбачених цим Кодексом.

Як зазначалось вище, одним зі способів збирання доказів є витребування та отримання від органів державної влади, органів місцевого самоврядування, підприємств, установ та організацій, службових та фізичних осіб речей, документів, відомостей, висновків експертів, висновків ревізій та актів перевірок. На вказаний шлях збирання доказів щодо встановлення та існування майна, на яке можливо накласти арешт, законодавець прямо вказав у ч. 1 ст. 170 КПК України.

У науковій думці, як правило, витребування та отримання речей, документів, відомостей, висновків експертів, висновків ревізій та актів перевірок прийнято розділяти на два самостійні способи збирання доказів, враховуючи, що в разі витребування ініціатива походить від суб'єктів кримінального провадження, в разі отримання - від інших осіб [5, с. 280-281; 6, с. 7-10; 7, с. 86; 8; с. 251].

Водночас думки вчених різняться щодо процесуальної форми збирання доказів шляхом витребування документів, відомостей тощо. Безпосередньою підставою наявності такої різносторонності думок є відсутність у кримінальному процесуальному законі регламентованої процедури таких дій.

Так, на думку окремих учених, витребування може здійснюватися шляхом направлення вимог, доручень, запитів [9, с. 227; 10, с. 60], приймання рішення у формі постанови $[11$, с. $137 ; 7$, с. 87 ; 8, с. 254], а інші ж указують, що з огляду на те, що кримінальне процесуальне законодавство не містить вимог до форми, змісту, строків реалізації та відповідальності за невиконання вимоги слідчого щодо витребування документів чи відомостей, єдиною законною можливістю отримати документи чи інформацію про факти є виключно інститути тимчасового доступу й обшуку $[12$, с. $142 ; 13$, с. 342].

Стосовно здобуття доказів шляхом проведення процесуальних дій не можливо не погодитись, що найбільш дієвою процесуальною дією серед усіх передбачених заходів забезпечення є тимчасовий доступ до речей і документів, який регламентується главою 15 КПК України. 
Згідно зі ст. 159 КПК України тимчасовий доступ до речей і документів полягає в наданні стороні кримінального провадження особою, у володінні якої знаходяться такі речі й документи, можливості ознайомитися з ними, зробити їхні копії та вилучити їх (здійснити їх виїмку).

Відповідно до положень глави 15 КПК України тимчасовий доступ до речей і документів здійснюється на підставі ухвали слідчого судді, суду, постановленої за результатами звернення з клопотанням прокурора або слідчого, погодженого 3 прокурором.

Водночас неодноразово в науковій думці підіймалося питання співвідношення таких процесуальних дій, як витребування та отримання речей, документів чи копій документів (ч. 2 ст. 93 КПК України), тимчасовий доступ до речей чи документів (ст. ст. 159-166 КПК України) та обшук (ст. 234 КПК України).

У даному випадку в науковій думці присутня єдність позиції, що витребування та отримання здійснюються на підставі звернення чи рішення слідчого або прокурора, а тимчасовий доступ до речей і документів та обшук - на підставі ухвали слідчого судді, при цьому витребування речей і документів та тимчасовий доступ до речей $і$ документів не передбачає застосування примусових заходів, оскільки відомо місце знаходження та володілець речей і документів, на відміну від здійснення обшуку [11, с. 139-140; 13 , c. $342-343 ; 6$, c. 6-7].

Останнім зі способів збирання доказів $€$ одержання доказів на території іноземної держави в результаті здійснення міжнародного співробітництва під час кримінального провадження.
Загальні засади та порядок здійснення міжнародного співробітництва під час кримінального провадження регулюється розділом IX КПК України.

Згідно 3 п. 1 ч. 1 ст. 541 КПК України міжнародна правова допомога визначається як проведення компетентними органами однієї держави процесуальних дій, виконання яких необхідне для досудового розслідування, судового розгляду або для виконання вироку, ухваленого судом іншої держави або міжнародною судовою установою.

Процесуальний порядок міжнародної правової допомоги під час проведення процесуальних дій регулює глава 43 КПК України, в якій визначаються вимоги до запиту про міжнародну правову допомогу та наслідки виконання запиту в іноземній державі.

Висновки 3 дослідження. Проведене досліДження дозволяє встановити, що виявлення та розшук майна, на яке може бути накладено арешт, здійснюється способами, визначеними в ст. 93 КПК України, зокрема шляхом проведення слідчих (розшукових) дій та негласних слідчих (розшукових) дій, витребування та отримання від органів державної влади, органів місцевого самоврядування, підприємств, установ та організацій, службових та фізичних осіб речей, документів, відомостей, висновків експертів, висновків ревізій та актів перевірок, проведення інших процесуальних дій, передбачених цим Кодексом, та одержання доказів на території іноземної держави в результаті здійснення міжнародного співробітництва під час кримінального провадження.

\section{Література}

1. Про Національне агентство України з питань виявлення, розшуку та управління активами, одержаними від корупційних та інших злочинів : Закон України від 10.11.2015 р. № 772-VIII. URL: https://zakon.rada.gov.ua/laws/show/772-19\#Text

2. Кримінальний процесуальний кодекс України : Кодекс України, Закон України від 13 квітня 2012 p. № 4651-VI. URL: https://zakon.rada.gov.ua/laws/show/4651-17/conv\#Text

3. Кримінальний процес : підручник / Р.І. Благута та ін. ; за заг. ред. А.Я. Хитри, Р.М. Шехавцова, В.В. Луцика. Львів : ЛьвДУВС, 2019. Ч. 1. 532 с.

4. Про затвердження Порядку взаємодії при розгляді звернень органів, що здійснюють досудове розслідування, прокуратури та виконанні запитів іноземних держав щодо виявлення та розшуку активів. Спільний наказ Національного агентства з питань виявлення, розшуку та управління активами, одержаними від корупційних та інших злочинів, Національного антикорупційного бюро України, Генеральної прокуратури України, Служби безпеки України, Міністерства внутрішніх справ України, Міністерства фінансів України від 20.10.2017 p. № 115/197-o/297/a/869/857. URL: https:// zakon.rada.gov.ua/go/z1342-17

5. Кримінальний процесуальний кодекс України : науково-практичний коментар : У 2 т. / В.Я. Тацій та ін. Харків, Право. 2012. Т. 1.768 с.

6. Ковальчук С.О. Способи збирання речових доказів стороною обвинувачення. Часопис Національного університету «Острозька академія». Серія «Право». 2014. № 2 (10). С. 1-24. URL: https://j.oa.edu.ua/articles/2014/n2/14kosdso.pdf

7. Вапнярчук В.В. Витребування та отримання, проведення інших процесуальних дій як способи збирання доказів у кримінальному провадженні. Науковий вісник Херсонського державного 
університету. Серія: Юридичні науки. 2015. Вип. 3 (3). C. 85-89. URL: http://nbuv.gov.ua/UJRN/ Nvkhdu_jur_2015_3\%283\%29_21

8. Ковтун О.В. Витребування та отримання як способи збирання доказів у кримінальному провадженні про злочини, пов'язані 3 перешкоджанням професійній діяльності журналістів. Юридичний бюлетень. 2017. Вип. № 5. С. 249-255. URL: http://www.lawbulletin.oduvs.od.ua/archive/ 2017/5_2017/41.pdf

9. Капліна О.В. Збирання доказів сторонами кримінального провадження. Актуальні проблеми доказування у кримінальному провадженні : матер. Всеукр. наук.-пр- акт. Інтернет-конф. (Одеса, 27 листопада 2013 р.). Одеса : Юрид. літ., 2013. С. 223-229.

10. Фаринник В.I. Особливості формування доказів та доказування в кримінальному судочинстві. Харків, 2013. 96 с.

11. Азаров Ю.І, Хабло О.Ю., Конюшенко Я.Ю. Окремі питання збирання доказів у кримінальному провадженні. Юридична наука. 2015. № 5. С. 135-141. URL: http://nbuv.gov.ua/UJRN/jnn_2015_5_16

12. Ковальчук С.О. Витребування й отримання речей як спосіб збирання речових доказів стороною обвинувачення: теоретичні концепції, нормативне закріплення та практичне застосування. Науковий вісник Херсонського державного університету. Серія «Юридичні науки». 2014. Вип. 5. Том 3. C. $140-145$.

13. Чемерис I.М. Проблемні питання збирання доказів у кримінальному провадженні. Порівняльноаналітичне право. 2017. № 5. С. 341-343.

\section{References}

1. Pro Natsionalne ahentstvo Ukrainy z pytan vyiavlennia, rozshuku ta upravlinnia aktyvamy, oderzhanymy vid koruptsiinykh ta inshykh zlochyniv : Zakon Ukrainy vid 10.11.2015 № 772-VIII. [On National Agency of Ukraine for finding, tracing and management of assets derived from corruption and other crimes : The Law of Ukraine from 10.11.2015 № 772-VIII]. URL: https://zakon.rada.gov.ua/laws/show/772-19\#Text. [in Ukrainian].

2. Kryminalnyi protsesualnyi kodeks Ukrainy : Zakon Ukrainy vid 13.04.2012 № 4651-VI. [Criminal Procedure Code of Ukraine: Law of Ukraine from 13.04.2012 № 4651-VI]. URL: https:// zakon.rada.gov.ua/ laws/show/4651-17\#Text [in Ukrainian].

3. Blahuta R. I., Hutsuliak Y. V., Dufeniuk O.M. and others (2019). Kryminalnyi protses: pidruchnyk. Ch. 1 [Criminal procedure: a textbook. P. 1]. Lviv: LvDUVS, 2019. [in Ukrainian].

4. Pro zatverdzhennia Poriadku vzaiemodii pry rozghliadi zvernen orhaniv, shcho zdiisniuiut dosudove rozsliduvannia, prokuratury ta vykonanni zapytiv inozemnykh derzhav shchodo vyiavlennia ta rozshuku aktyviv. Spilnyi nakaz Natsionalnoho ahentstva z pytan vyiavlennia, rozshuku ta upravlinnia aktyvamy, oderzhanymy vid koruptsiinykh ta inshykh zlochyniv, Natsionalnoho antykoruptsiinoho biuro Ukrainy, Heneralnoi prokuratury Ukrainy, Sluzhby bezpeky Ukrainy, Ministerstva vnutrishnikh sprav Ukrainy, Ministerstva finansiv Ukrainy vid 20.10.2017 № 115/197-o/297/a/869/857. [On approval of the Procedure for interaction in the consideration of appeals of bodies conducting pre-trial investigation, the prosecutor's office and the execution of requests of foreign states to finding and tracing for assets. Joint Order of the National Agency of Ukraine for Finding, Tracing and Management of Assets Derived from Corruption and Other Crimes, the National Anti-Corruption Bureau of Ukraine, the Prosecutor General's Office of Ukraine, the Security Service of Ukraine, the Ministry of Internal Affairs of Ukraine, the Ministry of Finance of Ukraine from 20.10.2017 № 115/197-o/297/a/869/857]. URL: https://zakon.rada.gov.ua/go/z1342-17. [in Ukrainian].

5. Tatsiy V. Y., Bandurka O. M., Portnov A. V., Pshonka V. P. and others (2012). Kryminalnyi protsesualnyi kodeks Ukrainy: naukovo-praktychnyi komentar: U 2 t. T. 1 [Criminal Procedure Code of Ukraine: scientific and practical commentary: In 2 books. Book 1]. Kharkiv, Pravo. [in Ukrainian].

6. Kovalchuk S. O. (2014). Sposoby zbyrannia rechovykh dokaziv storonoiu obvynuvachennia [Methods of gathering material evidence by the prosecution]. Chasopys Natsionalnoho universytetu «Ostrozka akademiia». Seriia «Pravo». V. 2 (10), pp. 1-24. URL: https://lj.oa.edu.ua/articles/2014/n2/14kosdso.pdf. [in Ukrainian].

7. Vapniarchuk V. V. (2015). Vytrebuvannia ta otrymannia, provedennia inshykh protsesualnykh dii yak sposoby zbyrannia dokaziv u kryminalnomu provadzhenni [Requesting and receiving, other procedural actions as a means of gathering evidence in criminal proceedings]. Naukovyi visnyk Khersonskoho derzhavnoho universytetu. Seriia: Yurydychni nauky. V. 3(3), pp. 85-89. URL: http://nbuv.gov.ua/UJRN/ Nvkhdu_jur_2015_3\%283\%29_21. [in Ukrainian].

8. Kovtun O. V. (2017). Vytrebuvannia ta otrymannia yak sposoby zbyrannia dokaziv u kryminalnomu provadzhenni pro zlochyny, poviazani z pereshkodzhanniam profesiinii diialnosti zhurnalistiv [Requesting 
and receiving as a means of gathering evidence in criminal proceeding on crimes related to interference with the legitimate professional activities of journalists]. Yurydychnyi biuleten. V. 5, pp. 249-255. URL: http://www.lawbulletin.oduvs.od.ua/archive/2017/5_2017/41.pdf. [in Ukrainian].

9. Kaplina O. V. (2013). Zbyrannia dokaziv storonamy kryminalnoho provadzhennia [Gathering of evidence by the parties to criminal proceedings]. Aktualni problemy dokazuvannia u kryminalnomu provadzhenni : mater. Vseukr. nauk.-pr- akt. Internet-konf. Odesa: Yuryd. lit. Pp. 223-229. [in Ukrainian].

10. Farynnyk V. I. (2013). Osoblyvosti formuvannia dokaziv ta dokazuvannia v kryminalnomu sudochynstvi [Features of the formation of evidence and proof in criminal proceedings]. Kharkiv. [in Ukrainian].

11. Azarov Y. I, Khablo O. Y., Koniushenko Y. Y. (2015). Okremi pytannia zbyrannia dokaziv u kryminalnomu provadzhenni [Some issues of gathering evidence in criminal proceedings]. Yurydychna nauka. V. 5, pp. 135-141. URL: http://nbuv.gov.ua/UJRN/jnn_2015_5_16. [in Ukrainian].

12. Kovalchuk S. O. (2014). Vytrebuvannia y otrymannia rechei yak sposib zbyrannia rechovykh dokaziv storonoiu obvynuvachennia: teoretychni kontseptsii, normatyvne zakriplennia ta praktychne zastosuvannia [Requesting and receiving objects as a method of gathering material evidence by the prosecution: theoretical concepts, normative consolidation and practical application]. Naukovyi visnyk Khersonskoho derzhavnoho universytetu. Seriia «Iurydychni nauky». V. 5, pp. 140-145. [in Ukrainian].

13. Chemerys I. M. (2017). Problemni pytannia zbyrannia dokaziv u kryminalnomu provadzhenni [Problematic issues of gathering evidence in criminal proceedings. Porivnialno-analitychne pravo]. V. 5, pp. 341-343. [in Ukrainian]. 